\title{
SEARCHING FOR THE HIDDEN STORY IN BEN MARAIS' THEOLOGY
}

\author{
Hans SA Engdahl \\ Department of Religion and Theology \\ University of the Western Cape
}

\begin{abstract}
BJ Marais' theology is seemingly mainline Protestant with a focus on the New Testament and the Christ event. However, not least a close reading of his unpublished dissertation on the early church and his other major writings reveals apophatic tendencies. He continuously drew inspiration from the early church as well as from the ecumenical movement (World Council of Churches), while the South African church and his people remained a major concern. Here three stories are reflected: The Christ event, the sad and unresolved South African story and the hidden story of how the early church handled slavery. Tensions between these stories are never resolved. In addition he remains undecided on a number of theological issues.
\end{abstract}

Key Words: Ben Marais, 'Christelike broederskapsleer', Christology, The early Church, Slavery, Ecumenical Movement, Colour or Race, Conservative and Radical Principle, The South African church

I have been in conversation with BJ Marais (1909-1999) for the last 15 years, not in a personal relationship as I never had the opportunity to meet him, but through his texts. ${ }^{1}$ It is a conversation at least indirectly as I have never stopped being inspired by his words and in being so, came back to him asking basic questions about theology. There is also a story in Ben Marais' theology. The story is evident enough, but the intriguing thing is that what I would like to call his third level story is largely hidden. We therefore have to be in pursuit of this story. However there is a second story in between relating to God's dealing with his church and the peoples of South Africa that is rather disconcerting.

The primary story is to Ben Marais no doubt what should be called the Christ event. Here he is in line with current ecumenical thinking from the first General Assembly of the World Council of Churches (WCC) in Amsterdam 1948 and for the next two decades when the Christological emphasis was dominant. Rather than being confined to $a$ particular salvation history view Marais' thinking clearly emphasizes the Christ event. It is a New Testament theology, masterly making use of contemporary theology. His focus on 'Christelike Broederskapsleer' helps him to develop a theology that contains a Christian Ethics based on the New Testament. ${ }^{2}$ It is a theology that integrates ethics and that is grounded in the fatherhood of God and the sonship of Christ. What comes out is a personal and social ethics based on the New Testament.

Christ's coming is an event and herein the dynamics lies. It builds its case on a theology

See my dissertation, Theology in Conflict Readings in Afrikaner Theology. The Theologies of FJM Potgieter and BJ Marais. Frankfurt am Main: Peter Lang, 2006.

2 See BJ Marais, 'Die Christelike broderskapsleer: sy agtergrond en toepassing in die vroeë kerk'. Stellenbosch, 1946 (diss) 
of change; it is a theology that reflects on how the gospel finds its way across the world in terms of mission, and in doing that creating new branches of the ecumenical church; what that is, is unresolved; that is why the Christ event as the lead story has sparked off two other stories largely in contradiction, one hesitant and 'moribund', the other liberative. One should perhaps already here reveal that the third and decisive story is intricately linked up with his account of the early church and slavery.

There has never been an inner urge to document and cover everything he has said and written on my part. His whole life in academia and church (including synods) is rich and the fact that he was at first a student chaplain and then a professor for many years just underlines his deep involvement with the church on campus and his close association with generations of students.

My scope is more limited but still essential. I have concentrated on his major writings as a theologian and I have scrutinized those writings in, what could rightly be called, a close reading. ${ }^{3}$ Thus leaving out what he might have said in church politics and student politics I am somehow disregarding a very important context. I do it on purpose and I suggest that in doing so I am able to uncover things that otherwise might have remained undiscovered. My conversation with him and my study of his theology is thus confined, is immanent, in such a way that the inner core of his thinking is laid bare. There are, however, two contexts of great importance within which Marais work has to be understood and that I also have had to recognise, even though indirectly, namely that of a racially separated South Africa with an equally separated church, and the ecumenical movement.

I will then deal with the theology of Ben Marais under the following four headings. Firstly, I will do what he himself did, even though in a much reduced way, namely paint the main theological content with broad strokes, on one canvas, which would reflect the emphasis on the one event; that is to say, the salvation history with its Christological emphasis and this history's impact in church and world. Secondly, I will look at the apophatic side or tendencies in Marais' work, which are very apparent to me, even though he would not have used that word.

Thirdly, I want to highlight a very profound side to his theology that has left more than one reader wondering whether he himself knows what he is talking about. My contention is that he knows perfectly well what he is talking about and that he does what he does with a purpose. This is his tendency not to reach conclusive opinions on a number of matters of basic theological importance, but instead, to leave them hanging in the balance. The question is whether he is merely sitting on the fence or whether he in fact develops what I call an emphatic 'undecidability'.

Fourthly, having uncovered three clear tendencies, the fact that he always without exception paints with the broad brush, that he leans towards the apophatic, and that he leaves a number of theological concerns undecided, it is not wholly unreasonable to ask whether this consistent tendency towards a grand, open-ended design is done for a particular purpose. Is there a hidden agenda? Is there a story somewhere told that is not apparent at first sight? My contention is that in giving account of the early church and slavery Marais draws up the contours of an ecclesiology on which he also reflects theologically. However, this story of the early church and slavery and its interpretation is largely a hidden story in Marais' theology.

In my dissertation I also had a second reading on basis of the first which I have called a contrast reading. I make use of deconstruction and fundamentalism as analytical tool and contrasting grid. Here I refrain from applying such a contrast reading and stay with what a close reading might yield. 


\section{Painting with Broad Strokes}

In his pursuit of a viable Christian teaching on communitarian life, in Marais' terms 'Christian brotherhood', he draws his insights from a relatively broad Protestant scholarship of the Bible. He later explored the early church, that is, the church's first three hundred years, and looks for similar teachings there. He also looks at how the social teaching of Jesus and Paul is applied in the early church. In all his texts there are a number of assumptions that are never declared. For example, a main line Protestant Word of God theology is taken for granted. This causes some delicate problems. For example, when establishing what Christian brotherhood is, the Bible, and the New Testament in particular, becomes normative, while texts from the early church are not. Yet in the end Marais still renders not only a certain credibility but also a certain normativity to some of the texts of the early church fathers.

As mentioned above, Marais is also deeply affected by two contexts, namely racial separation in South Africa, and in the South African church on the one hand and the ecumenical movement at large on the other. This movement, especially as it was manifested in the World Council of Churches remained a constant inspiration throughout his life as does the early church. His doctoral studies on the early church played a fundamentally important role. His long association with the ecumenical movement should also be seen as a continuous inspiration helping him to keep alive basic insights from the early church and enabling him to see beyond the confines of church life at the time. He was, for example, able to attend the Conference for World Mission and Evangelism, CWME, at Tambaram, India, in 1938, and two WCC general assemblies, Evanston, USA, in 1954 and New Delhi, India, in 1961.

He was, in other words, very well acquainted with a historical and an international ecumenical perspective. In dealing with the South African church and wider community, however, he runs into deep trouble. It is as if the two sources, from which he continually draws inspiration, stop functioning. One or two comments of his regarding the practical necessity of keeping apartheid in tact nearly capsize his whole theological corpus. We will come back to this later.

Marais' writings could probably be organized in a number of ways. Here the following four areas may be mentioned: New Testament theology and ethics, the early church fathers, the question of race and the South African church and finally the ecumenical movement. The first two of these are foundational in relation to the other two.

\section{New Testament Theology and Ethics}

Marais has a straightforward theistic approach and he draws directly from the monotheistic belief in the Old Testament, claiming that the Christian faith did not create a new concept of God but simply took over the Old Testament view. He also claims that worldview and faith convictions determine the comprehension of the social life of human beings.

While he maintains that the Christian faith has accepted God as portrayed in the Old Testament, he also says that a new quality has come in, clearly seen in the New Testament. But it is merely a sharpening and deepening of what is already there. ${ }^{4}$ It is obvious that this God is "the personal, ethical self-revealing God." The concept of God is not the result of a long process of development but a matter of revelation. This purity of God as the one and only, as sovereign and as righteous, is taken over by the Christian church. God is further the moral will of the universe, giving us a law to follow, but also the Father of all.

Marais, pp. 99 and 112.

Ibid, p. 93; James Orr, The Christian View of God and the World. Edinburgh, 1893, p. 75. 
Marais puts emphasis on God as Father and again compares the two testaments. It is not a matter of changing the concept. Referring to different sources he comes up with a condensed view saying that the New Testament makes the term Father both more limited and more extensive. ${ }^{6}$ It is more limited as Jesus makes this term a description of his relation to God. It becomes deeply personal and comes to describe the relationship between the Father and the Son. The Aramaic word 'Abba' comes into play. ${ }^{7}$ Here lies also the foundation of the social and ethical life of human beings, which Marais calls the doctrine of 'Christian brotherhood'. What is developed here is the right and definite relationship between fatherhood, being child of God and 'brotherhood'. However, through the same intimate relationship between the Son and the Father the door is opened and extended to all. There is indeed a common fatherhood of all as God the creator. ${ }^{8}$

The deep and intensively personal relationship between the Father and the Son has a profound impact on all other relationships. We are no longer children of God simply by nature but are adopted children (sons and daughters) through the grace flowing from this new relationship. Physical characteristics or nationalistic views here have no role to play. ${ }^{9}$ The fatherhood of God is providential and makes Epicurean and Stoic notions of life as 'chance' and 'fate' null and void. ${ }^{10}$

This point of departure makes it possible to construct the basis of a doctrine of the human. The theistic standpoint could then be summed up in two affirmations: The human belongs to God and is created in God's image. ${ }^{11}$

In other words, God's value of the human is very high and that is also demonstrated by Christ. At the same time, even if all humans are equal before God, there is within the created orders a large measure of inequality. Marais here also gets keen support from Emil Brunner. However, he would at another point quote Lactantius of the early church as saying that God's will is "that all should be equal."12

Brotherhood, only mentioned once in the Bible (1 Pet. 2.17), could be seen as an analogy to God's fatherhood. Christian brotherhood is then a reality for those who experience salvation in Christ. Again, Marais' usage of brotherhood rather than 'brother', a much more used concept in the New Testament, opens up a most valuable discussion. This term makes it possible for him to lay the stress on the community and not just on the individual. But characteristic to him is to stress the individual as well as the communal perspective at the same time. He would use language from Harnack, ${ }^{13}$ emphasising the decisive role of the individual soul in relation to God and Christ, but he would also not hesitate to quote the Anglo Catholic theologian Charles Gore who says that Christianity probably is the least individualistic of all religions. ${ }^{14}$

With God's fatherhood as point of departure Marais also says that an essential part of

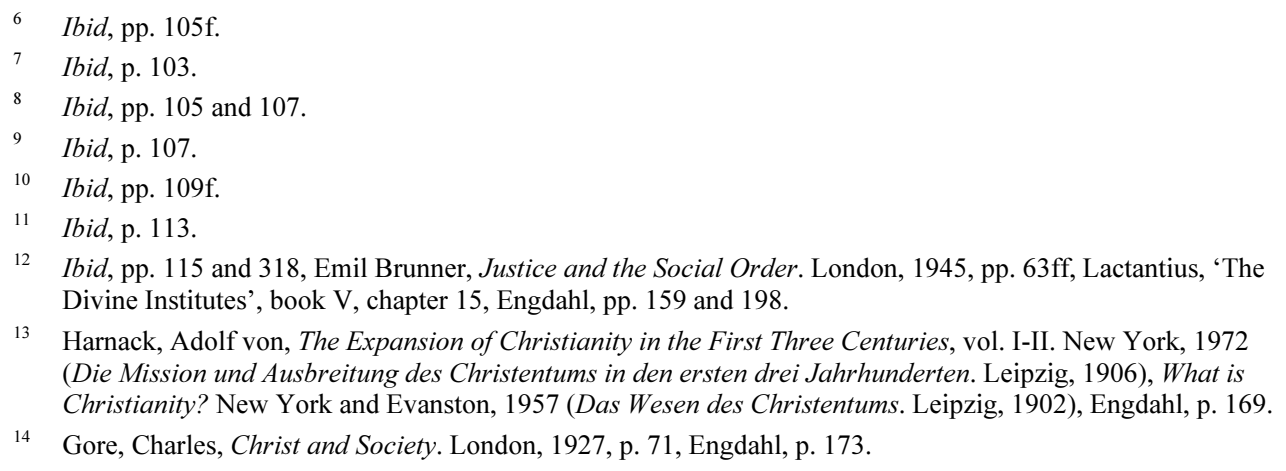

13 Harnack, Adolf von, The Expansion of Christianity in the First Three Centuries, vol. I-II. New York, 1972 (Die Mission und Ausbreitung des Christentums in den ersten drei Jahrhunderten. Leipzig, 1906), What is Christianity? New York and Evanston, 1957 (Das Wesen des Christentums. Leipzig, 1902), Engdahl, p. 169.

14 Gore, Charles, Christ and Society. London, 1927, p. 71, Engdahl, p. 173. 
the Christian doctrine was the conviction of "the unity and brotherhood of all men". 15

In trying to establish what this brotherhood, this communitarian life means, one has to turn to the social teaching of Jesus. This in turn leads us to his numerous references to the kingdom of God. The question whether the message of Jesus had social implications, and if so how, was hotly debated in the $19^{\text {th }}$ and early $20^{\text {th }}$ century. Marais refers to socialist, liberal and more immanent interpretations without taking a definite stand. The social gospel theology of people like Rauschenbusch is presented. Marais comes out as saying that the kingdom of God had some social implications. He also concurs with Harnack's interpretation of Christ's parables as food for the soul in the first place. However, he is clear as to the relationship between social reform and personal salvation. Christ came for the latter, not for the former, but salvation in Christ would have social implications. ${ }^{16}$

Marais deals extensively with what could be said about the kingdom of God. Here he actually excels in the sense that he first says that Jesus left us quite unclear about how we should understand it and then comes up with an impressive balancing act of the various alternatives and is able to accommodate the following views in creative tension: The kingdom is for the individual soul and makes its presence felt only there; The kingdom is a social reality, already begun with Christ's ministry; It is eschatological and will come one day in full force renewing and changing everything; It is also a present reality and the church, through its communitarian life (brotherhood) is called to serve this kingdom and live its values; It is a present spiritual reality.

It is interesting to see how he can handle theologians such as Harnack and Schweitzer ${ }^{17}$ without hesitating in giving both due respect and space. The kingdom is growth according to Harnack but not according to Schweitzer. The kingdom is growth according to Marais but he goes further than Harnack and sees growth also in a social sense. ${ }^{18}$

This balancing act can be summed up in the following quotation of Charles Gore: "It was to be a community in the world but not of it ... based on the fullest recognition of brotherhood, under the Fatherhood of God, to the exclusion of any selfish claim for a privileged position, and on the acknowledgement in every single soul of an equal and infinite worth.,"19

In conjunction with establishing what the social teaching of Jesus entails, Marais also deals with the orders of creation and what to him is of great importance, namely the conservative and radical principle. He showed due respect to the Reformed tradition by talking about God's providential arrangements in creation under common grace. At the same time and seeing Marais' work as a whole, these aspects play little or no role in his theology. What plays a decisive role on the other hand is this principle, conservative and radical. Typically this principle would be at work when for example Paul states that a Christian must remain faithful and serve the present order on the one hand, and on the other state that in Christ the disciple is a new creation. Both legs of this dual principle are then at work.

It becomes something more like a method. He takes this principle from Ernst Troeltsch. ${ }^{20}$

15 Marais, ibid, p. 123, quotation from WM Ramsay, The Church in the Roman Empire. London, (no year), p. 345.

16 Ibid, p. 145

17 See in particular Albert Schweitzer, Geschichte des Leben-Jesu-Forschung. Tübingen, 1933 (1913), and ibid., The Mystery of the Kingdom of God. London, 1925.

$18 \quad$ Ibid, p. 152

19 Ibid, p. 160, quotation from Gore, p. 58.

20 Ibid, p. 161, Troeltsch, Die Soziallehren der Christlichen Kirchen und Gruppen. Tübingen, 1923, pp. 70-80. Se also the English translation, The Social Teaching of the Christian Churches, vol. I-II. London, 1956, (fourth impression, first impression 1931), pp. 80ff. 
It certainly is an ingenious principle up to a point but can also be grossly abused. Marais falls victim to this more than once himself. Troeltsch discusses this principle more in detail and sees that it is used consistently in the ministry of Jesus as well as in that of Paul. But he also makes clear the great distinction: Jesus came and announced the radical message of the infinite worth of the individual human person on the one hand and the complete universality of his message on the other. In Paul he sees strong tendencies of accommodating the gospel message of Jesus to present society, slaves must stay slaves and Christians must not only tolerate but accept and respect worldly authorities as instituted by God. In the end Troeltsch also thinks that the principle is universally applicable also in the early church and there remains an underlying radicalism that constantly challenges the conservative elements. Marais however never makes mention of the clear tension that may be identified between the gospel message of Jesus and that of Paul. ${ }^{21}$

The principle expresses something very profound and lasting in the present world order before Christ's second coming; there is a tension between the old and the new. Jesus was himself not only radical but also conservative in the sense of accepting the order of the world, the Roman Empire, paying taxes to Caesar etc. Likewise it is not true that Paul wanted those who were slaves to remain in their condition. He certainly saw the radical principle as a powerful tool in the Christian church to change or rather totally undermine the system of slavery. Paul's own epistles speak the same language of radical renewal (Col. 3.9-11, Gal. 3.27-28). As Marais rightly demonstrates later on, the Christian church effectively undermined slavery, even if it took time. It was the radical part of the principle at work.

\section{The Early Church Fathers}

Marais then moves over to his actual subject, the early church. He is able to demonstrate in a fair way that what happens in the early church is in many ways consistent with the New Testament, the gospel and the first Christian community and church presented there. However, there are two obstacles that make it difficult to get the whole picture. With a Word of God theology it becomes difficult to critically analyse what is happening in the earliest church, be it the Pauline church or that of John. Secondly, having established the basic social teaching of Jesus and the inner workings of the Christian community, we now have an idea of how things should be run. But applying what the New Testament has yielded to the early church beyond the Scriptures becomes self-fulfilling: That which is on the same line as the New Testament gets attention, the rest is left by the way-side. Just to take one example; Marais at one stage quotes a text from Hermas the Shepherd without recording the well known fact that Hermas is extremely legalistic and church discipline goes well beyond what is ever mentioned in the Bible. ${ }^{22}$

Nevertheless Marais makes a substantial contribution in demonstrating that the early church to a large extent continued on par with the gospel tradition. This is particularly clear when it comes to 'Christian brotherhood', the Christian community and its openness to humanity at large, a sense of social and diaconal responsibility combined with an acute awareness of the parousia. He makes use of early fathers such as Tertullian, Ignatius, Justin Martyr, Origen and Chrysostom, the latter having lived much later than the period of the three first centuries of the Christian church.

The most substantial part is however where Marais applies, as he calls it, the social

21 Ibid, p. 162, Troeltsch, ibidem.

22 Ibid, p. 202, 'The Pastor of Hermas' in Roberts and Donaldson (eds.), The Ante-Nicene Fathers. Grand Rapids, 1977, Vol II, p 50, Engdahl, pp. 175f. 
doctrine of Jesus (or the doctrine of the Christian brotherhood) to three different social problems. Two of them are taken straight from what was transpiring in the Roman Empire at the time, or at least in the Christian community, namely the question of slavery and the question of private ownership. The third issue is somehow misplaced; it is about racial differences. It is taken from the context of South Africa, not Mediterranean early church times. Whatever the case may be, Marais applies the social doctrine of Jesus to this third area as well and not without some gains. What he does is simply to state that by and large racial (ethnic etc) differences did not exist in any such form in the early church but what existed was a thinking that was a kind of contrariety. The early church was characterized by what is contrary to racial difference: Catholicity and universal character, tendencies towards cosmopolitanism and discussions about the possibility of salvation for all. ${ }^{23}$

Let us first say something about slavery and the early church. In the numerous quotations from church fathers it is evident that some consensus is forthcoming. Even though the church does not reject or condemn slavery as such as a societal phenomenon, in church and in the church's worship there is no distinction. What could well happen was for example that a slave owner had to receive the sacrament from a slave. "Slaves achieved equality with others in the religious sense and it could well be the case that rich people had to kneel before someone who had been a slave." 24 Some would stress the need for slaves to be patient and bide their time and accept slavery to continue, ${ }^{25}$ while some urged for as rapid change as possible. ${ }^{26}$ In all this Marais applies the conservative and radical principle saying that while accepting this evil in society the Christian 'brotherhood' or communitarian living consistently undermined and nullified the very phenomenon of slavery in its midst. Marais does this elegantly and convincingly.

The strength of his argument lies not least in the fact that he is able to point at, not just ideas of equality and rights, but an existing community, the church, which in its very life was called to live out this brotherly and sisterly love and acceptance.

As far as racial difference is concerned, one can wonder whether Marais had in mind finding an argument or two speaking directly to his South African situation. Be that as it may, two years after having finished his dissertation in 1946 he found himself in a country that soon enough would put apartheid and racial difference and separation in the statute books. As far as I know he never used these texts on slavery and the non-existence of racial difference in order to discredit what was going on in South Africa. However here he comes up with very substantial and exciting thoughts on the inspirational foundation of the early church. The non-existence of racial difference leads Marais to deliberate on three phenomena, universalistic thinking, cosmopolitanism and visions of seeing a 'salvation of all' scenario combined with a fusion of church and world.

Universalistic thinking in the sense of discarding or relativising tribal or ethnic difference had Justin Martyr's full support:

We who hated and destroyed one another, and would not make use even of the same fire with those of another tribe, because of their different customs, now, since the coming of

23 Ibid, pp. 229-326, Engdahl, pp. 184-212.

24 Ibid, p. 249.

25 Ibid, p. 256, 'Constitutions of the Holy Apostles' in The Ante-Nicene Fathers, vol.VII, Book IV, chapter XII, p. 436.

26 Marais refers frequently to Lactantius and especially to Chrystostom, for example, Lactantius, 'The Divine Institutes' in The Ante-Nicene Fathers, vol.VII, Book V, chapter XVII, p. 151, Chrystostom, 'Homilies on First Corinthians' in Philip Schaff (ed.), The Nicene and Post-Nicene Fathers. Grand Rapids, 1979, vol. XII, Homily XL, p. 248. 
Christ, live together, and pray for our enemies, and try to persuade those who hate us unjustly, that all who have lived in accordance with the good precepts of Christ, may come to a good hope of obtaining from God the Ruler of all things the same reward as ourselves. ${ }^{27}$

Secondly cosmopolitanism ${ }^{28}$ had support among some of the early fathers such as Tertullian and Tatian. Marais has the following from the latter: "As there is but one God there has to be but one societal government for all people. There cannot be numerous rulers. State must not be separated from state and education must be absolutely universal and equal for all people." 29

Thirdly, Marais quotes generously from the partly very speculative but greatly gifted Origen on apokatástasis pantón and the idea that God well may save all in the end. In combination with this idea Origen also reasons and to an extent speculates about how God has two ways of bringing his will through. He operates through his beloved church first of all, a church that is already spread across many nations and that knows no bounds as it is catholic and universal. In addition, God also operates directly through his creation and the world. On the other hand, there is this awareness that ultimately God's purpose is for the whole world and the 'new law' of Christ is not there for the sake of the church in the first place, but for the whole world. ${ }^{30}$

Origen may already anticipate his and others' resurrection status and thus be in such a status beyond this world. Inevitably Origen ends up in speculation. Marais having opened the door even for an Origen also has his doubts as he can see a link between church and world (empire) in what actually would take place later on through Constantine and the following history of the church: The new world church would simply take over some of the traits of the former Roman Empire. ${ }^{31}$ That was not exactly what Origen had in mind. ${ }^{32}$

\section{The Question of Race and the South African Church}

The question of race or colour warranted a study of its own which Marais also did. At the same time, as with so many others at this time, there is a pre-occupation with race and church. Marais does not enter the political arena regarding this issue but confines himself to the church. What is consistent in his thinking is that there is a negative correlation between the findings in the objective studies on race and colour and the life of the church in South Africa.

He indeed contributes towards the discussion on race or as he calls it, colour. He spends a year in the US studying the issue of race and racial segregation; he visits Brazil and eventually publishes a book on his findings, Colour, Unsolved Problem of the West. ${ }^{33} \mathrm{He}$ is especially disturbed by racist attitudes in the churches in the US, i.e. the way in which blacks are treated.

27 Ibid, pp. 318f, 'The First Apology of Justin' in The Ante-Nicene Fathers. Grand Rapids, 1981, vol. I, chapter XIV, p. 167.

28 A phenomenon enjoying renewed interest by some sociologists in the $21^{\text {st }}$ century, see for example Vertovec, Steven and Cohen, Robin (eds), Conceiving Cosmopolitanism. Theory, Context, and Practice. Oxford, 2002.

29 Ibid, p. 323, Tatian, 'Address to the Greeks', in The Ante-Nicene Fathers, vol. II, chapter XXVIII, p. 77.

30 See Origen, 'Against Celsus' in The Ante-Nicene Fathers. Grand Rapids, 1979, vol. IV, Book VIII, chapter LII, p. 659, and ibid, 'Against Celsus' in The Ante-Nicene Fathers, vol. IV, Book V, chapter XL, p. 561.

31 Marais, pp. 324f.

32 Origen, ibid, p. 668.

33 Cape Town and London, 1952. 
In his book he also mentions the dilemma South Africa finds itself in and says without much further ado that however true it may be that race in fact is a social construct without any real scientific meaning, in South Africa we cannot, for practical reasons, do away with racial separation, it remains, unfortunately, a practical necessity. In other words, his findings on the other side of the great waters do not have a particular message for the South African situation. Instead he takes up his earlier research on the early church and applies the conservative rather than the radical principle on his beloved country. To bring in the radical principle now would bring chaos, this is not possible: "Our own position in South Africa presents, in my opinion, more than sufficient justification for a policy of separate development and separate church institutions.",34

However, he is probably unhappy with having to make such a statement. He knows what is right but for practical reasons he cannot, as a responsible citizen, say otherwise, not at this time. And yet, as late as 1964, he cannot get himself to condemn the present system of apartheid as its abolishment would still spell disaster. It remains a fact that Marais never came out into the open in condemnation of this system, no matter how clear he was about it in principle and in his theological argument. It is therefore somewhat surprising that a theologian such as Bonganjalo Goba can say the following without any further qualification: "Professor Ben Marais has had the courage to challenge particularly members of his community and the world to eradicate the evil of racism for many years." 35

\section{The Ecumenical Movement}

We may also not forget the other important context, that of the ecumenical movement. It played a very significant role in Marais' theological life and was together with his research on the early church a constant inspiration. He never left his 'foundational principles' retrieved from the early church and yet the continued advances within the ecumenical movement rather confirmed and underlined his convictions of the importance of one, visible, catholic church on earth. This is not the place to comment on how his involvement in the WCC influenced his theology. Three examples will however be given that show how his theological stance was confirmed or expected to be confirmed.

He was himself active in the WCC when it was established that other member churches must not interfere in a particular member church's affairs. Membership in the World Council would not be built on such interference. However from the late 1970s onwards it was decided in ecumenical circles that apartheid could not be given support by any member church as it had received status confessionis. By that time Marais was no longer an active ecumenist. He may very well have understood what was to come but I do not know what his comments were.

He was no doubt exhilarated over that unity that had already been achieved in the World Council. A common denominator was the Christological perspective, which sums up his own theology. Despite the condemnatory statements against racism at the general assembly of the WCC in Evanston in 1954, Marais was thrilled about being there and being part of the fellowship. His enthusiasm is well summed up in this paragraph.

But what surprised was the fact that despite profound differences, the one main speaker after the other came through with a Christocentric message. These men came from different great traditions and from different countries. But Prof Schlink from Heidelberg, Germany,

34 Marais, Colour, Unsolved Problem of the West, pp. 298f.

35 'The Problem of Racism Revisited: a Theological Critique' in JW Hofmeyr and WS Vorster (eds.), New Faces of Africa. Essays in Honour of Ben Marais. Pretoria: UNISA, 1984, pp. 96-103, p.101. 
DT Niles from Ceylon, Reinhold Niebuhr from the USA, Prof Georges Florofsky from the Greek Orthodox Church, Bishop Berkgraf (Berggraf) from Norway, Bishop Dibelius from Germany and Prof Hromadka from Czechoslovakia, one after the other delivered such positive and challenging, Christological messages that we in a much deeper sense had come to the realization of our essential unity in faith than that of (a realization of) our differences. That affected us all and we were made to realize that there is a much closer and deeper unity in faith than the (kind of unity) we often are aware of. ${ }^{36}$

Above all there is here reason to mention the inherent ecumenical qualities in Marais' theology. As I have argued in my dissertation, Marais has in his research developed what I would call a 'communitarian responsibility', namely the fact that his point of departure is the church as 'brotherhood', a fellowship that has ethical and social qualities. He argues convincingly that slavery was undermined thanks to the church being such a communitarian entity. He did this in the middle of the 1940s, during the Second World War, a few years before apartheid came into the statute books. Because of this emphasis on a social and ethical quality in the early church, what comes naturally to him is the stress on visible unity of the church in line with what unfolded in the ecumenical movement from the inception of the WCC in $1948 .^{37}$

Fifty years later, after a long period of World Council involvement in social and political issues, a study is initiated that deals with the wide gap in the ecumenical movement that was never bridged, namely that between Faith and Order and Life and Work. In a study series of three reports, ${ }^{38}$ eventually called Ecclesiology and Ethics, it was spelt out that what is done and said for and in the world somehow has to be demonstrated in the church. The church is an entity in itself, a community with ethical qualities. Despite some hesitation at first this document clearly talks about the church as a moral community. ${ }^{39}$

It goes without saying that the work that Marais had been doing 50 years previously was on exactly this line. In addition he had substantial evidence; through his studies on the early church and slavery he knew what he was talking about. The early church would not have survived with a segregated, separatist attitude within itself on this issue.

\section{Concluding Comments}

As a way of summary one should add the following. Marais' work as a whole also offers a continuous comment on the situation of the Christian church in South Africa. That is a story of its own on a different level than the other two and turns out to be as already said, moribund. It is ambiguous and contradictory in an unsatisfactory way. There is a powerful glimpse of something more when Marais speaks about the fact that there are no Scriptural foundations for apartheid whatsoever. ${ }^{40}$ This consistent statement angered many Dutch Reformed people. At the same time, however, he also persisted in saying that for all practical purposes apartheid would have to remain in place. Marais, in telling his South African story, is not only geared toward the church even if such an impression is given. There is a multiplicity of things to be taken into account. It is for example my conviction that 'level of civilization' is a concept that had a defining role in telling the South African story.

6 Marais, Die Kerk deur die Eeue. Pretoria, 1960, p. 137.

37 Marais, 'The Church in the Contemporary World' in Geyser, Marais et al. (eds.), Delayed Action! Pretoria, 1962, pp. 29-42, p. 39, Engdahl, pp. 230f.

38 Costly Unity, Costly Commitment and Costly Obedience.

39 Ecclesiology and Ethics. Ecumenical Ethical Engagement. Moral formation and the Nature of the Church, Thomas F Best, and Martin Robra, (eds.), WCC, Geneva, 1997.

40 See for example Marais, 'Die Christelike broederskapsleer', p. 315, Engdahl, p.224. 
The following two comments on slavery and civilization may substantiate my conviction. Slavery in the Roman Empire was 'invisible' in the sense that the slaves did not look different but blended completely with the other people, like in Rome; at one stage it was suggested that all slaves should be marked out with a bracelet like the Jews in Germany in the $20^{\text {th }}$ century. The Senate of Rome got a scare as they discovered that the slaves were in the majority in the streets and they quickly ordered a reversal of this decision. Why did Marais tell this story in detail if not to say that South Africa is different? ${ }^{41}$

Marais at another point describes how the black people/race had a misfortune as they ended up outside the Christian civilization, which had become 'all white'. In the $19^{\text {th }}$ and $20^{\text {th }}$ centuries there thus developed a sharp divide between the West/whites and Africa/ blacks, in terms of race but also in terms of level of civilization.

In other words, circumstances in South Africa were different from the rest of the world with a majority with a much lower civilization and a small Christian (white) minority representing the Christian civilization. According to him a mixing of these civilizations would spell disaster. ${ }^{42}$

These factors have a direct bearing on the fragmented story that Marais tells as a reflection on the way of the church in South Africa. It is a story that is unredeemed, caught up in contradictions that are not constructive. Fortunately, for the immanent reader of his texts, this is not the end of the story. It cannot be that the great inspiration to these broad strokes on the canvas from the early church and from the world ecumenical movement could be allowed to end up in the practicalities of post Second World War South Africa.

\section{Apophatic Tendencies}

A critical theology should be about putting serious questions to what seems to be fundamental faith convictions. There is in the early church already an apophatic tradition doing just that. 'Apophatic' is from the Greek apóphasis meaning denial, negation. In apophatic theology concentration is on what cannot be said about God and underlying this is of course the conviction that we as humans know pretty little about God, as even the revelations that are there have to be carried in earthen vessels.

It is of quite some import that this critical, apophatic reflection took place in the early church. Before formulas on Christ and God became too fixed there was also a greater freedom to think and shape concepts. The apophatic school would hold back from too illustrious and unwarranted expressions. Pseudo-Dionysios could say with reference to the Trinity that we are not dealing with ordinary numbers or set objects: They are neither three nor one "in our sense of the words". "Negative theology remains one of the most basic forms of critical theology, sometimes doing no more than sounding a warning note against the idea that we could secure a firm grip upon definitions of the divine." 43

It could also be about 'dispossession' in the sense that all we can do is to wait for God, and we end up with the most radical form of prayer, namely contemplation. This in turn is apóphasis, "the acknowledgement of the inadequacy of any form, verbal, visual or gestural, to picture God definitely, to finish the business of religious speech..."44

This kind of negative theology has a role to play not least when we speak in Trinitarian and Christological terms, which carry certain historicity and yet do not in any way empty

Ibid, p. 233, Engdahl, p. 195.

2 Marais, Colour, Unsolved Problem of the West, pp. 288ff., Engdahl, pp. $215 \mathrm{f}$.

3 Rowan Williams, On Christian Theology. Oxford, 2000, p. XV.

$44 \quad$ Ibid, p. 11. 
the mystery of God. This negative theology is indispensable. It helps us not to "delude ourselves that God's difference is merely that of one thing from another: We need to put down those formal markers (immutable, impassable, omnipotent, etc.) as a way of insisting that we cannot write a biography of God." This much we should agree upon: God's history that we know of is Jesus. ${ }^{45}$

A lot would speak against seeing Marais on an apophatic trend at all. He propounded a kind of mainline Word of God theology; he subscribed to Protestant Orthodoxy and his Christological emphasis fell nicely within this framework. And yet, this is not the whole truth. There are at least four factors that make Marais think in an apophatic direction. First he never gives in to speculation; he is simply not interested in that sort of thing. He has a task and is left with a commission that is overwhelming and that is enough. Secondly, he certainly makes do with the bare minimum. Even if he is keen to discuss many a thing but without taking a definite stand (see section on 'undecidability'), he in the end is more than content that there are certain basics that hold in all 'weather conditions'. ${ }^{46}$ Thirdly, Marais is deeply influenced by the early church in its first three centuries, in other words before the great councils of Nicaea, Constantinople, Chalcedon etc. He was acquainted with a period that was formative and open-ended. This period had its share of negative or apophatic theology and the inference is that it was easier and seen as more accurate to have such a critique in an environment where many things were in a flux. Come the great councils with definite formulas, which were in some ways utterly needed, and the scope of the apophatic had diminished drastically as such a stance could be seen as unorthodox. Fourthly, there was seemingly a kind of carefree restfulness, perhaps not unrelated to a condition of contemplation, in Marais' thinking that allows for taking the negative questions to heart.

\section{Undecidability}

After having realized what cannot be said about God there is an area where what can be said largely is open-ended. Marais had an ability not to say the definite word on many issues. Such an attitude is related to a critical theology that wants to scrutinize various attempts at giving God a 'biography'.

The question however is: Why was Marais undecided regarding certain theological questions? Many would say that he was undecided regarding how the church should act in apartheid society. He would be seen as sitting on the fence. I would argue that he was firm in his insistence on not applying his theological insights due to practical considerations. The discussion actually ends there. Let me give four other instances where he in a creative way opts for being undecided.

The first case is when he speaks about God as Father. The issue at stake is whether the understanding of God shifted in a decisive way with the arrival of Jesus. Did the New Testament bring in a new understanding of God that was not there before? The answer is interesting. It was not about a 'new' God at all. The New Testament certainly took over the monotheistic view that was there. It was merely a deepening of what was already there before. Jewish scholars such as Montefiore, who points out that the intimate relationship to God as Father was well known within Judaism, are articulating their view and are not gainsaid. The sensitive point is however reached when Marais brings in the radically new, the fact that Jesus is declared the Son of the Father like nobody else. Surely this is a new relationship that was not there before that should give the fatherhood of God a qualitatively

$45 \quad$ Ibid, p. 160.

46 He may here be likened to CS Lewis' kind of Christian Orthodoxy. 
new dimension? However, Marais does not seem to be worried about this. The authentic, new, radically deepened relationship between the Son and the Father is declared and stands as a pillar in his continued argument for what is 'brotherhood' or communitarian life. He is in other words comfortable with a situation where the Old Testament and Jewish view is given full scope at the same time as this radically new relationship is announced.

The second case deals with two closely related themes, that of the social teaching of Jesus and how the kingdom of God should be understood. We cannot go too much into detail as this is a big issue. However, here Marais really performs as the master of ceremonies asking questions like: "Did Jesus have a social agenda?", "Was the kingdom a present or an eschatological reality?", "Did Jesus concern himself with the individual in the first place or rather with the community?" All these questions are dealt with together and he makes frequent use of the great scholars of the day, Adolf von Harnack, Albert Schweitzer, Walter Rauschenbusch. Clearly, this time Marais would have to take a definite stand?

Harnack was dominating the scene quite a long way into the $20^{\text {th }}$ century. Of course Das Wesen des Christentums had to be taken seriously as well as his other seminal work on the mission of the church. A close analysis of Marais' way with Harnack is quite intriguing. The present reality of the kingdom is there, but he carefully avoids mentioning the radical stand of Harnack in his emphasis of the individual soul as Sitz im Leben of the kingdom. Marais did not deny it but was far more interested in other options, for obvious reasons. Now he plays out the radical eschatology of Schweitzer over against Harnack just as a matter of fact, agreeing with radical eschatology in the sense of eschatology being a real event to come, but still maintaining the kingdom as a real presence in this dispensation. He would agree with Harnack that the kingdom is in a state of growth just as the parables of Jesus tell, knowing pretty well that to Schweitzer this was an impossibility. But he transforms Harnack's enclosure in the soul completely, not denying the role of the human soul, but widening the whole concept saying that the kingdom was in growth also as a social reality, a very profound utterance indeed.

This statement again brings him closer to the social gospel theologians such as Rauschenbusch. He deals with socialist interpretations of Jesus' social teaching as well as the liberal social gospel interpretations of the day, but he never says whether he likes these ideas or not. Eventually, without him having said so much, one can fairly easily infer that he puts quite an emphasis on just the social aspect of the kingdom, but also on the social aspect of the church.

Yet, Jesus did not come for social reform in the first place but with something far more radical, a kingdom that would eventually transform the rest. In the end Marais succeeded in striking a balance between the spiritual and the social, the individual believer and the community of the faithful.

The third and the fourth cases are about phenomena in the early church already discussed above, such as cosmopolitanism and 'apokatástasis pantón', the salvation of all. Marais contends that cosmopolitanism could be seen as a natural outflow of the church being universal. He opens up for a discussion on these issues without taking sides. His background as Afrikaner was of course one of emphasis on nationalism as something God given. He also does not challenge that notion at all, nor does he defend it. He probably liked the dialectics that could be found between the two, nationalism on the one hand and cosmopolitanism on the other.

In the fourth case Origen saw a convergence or a possible fusion between church and world. God's law, as revealed in the Old Testament, was the right law for all and should be implemented. At the same time the church was through its catholic, universalistic nature 
embracing all and welcomed all in her midst. So what is Marais' stance here? He does not say. But it is not just a matter of citing what the early fathers say. There is more to it than that. Over against these views were a host of more traditional ones, firmly entrenched in Reformed theology: The outcome in terms of salvation is in the hands of God, but in the confined sense that he has already in his providence named those who are the elect, but this is a truth hidden in God. Marais does not present himself as the immutable Reformed theologian but he also does not refute any of the traditional Reformed wisdom. ${ }^{47}$

So why did Marais insist on being undecided? Why did Marais abstain from chiselling out a straight route for others to follow? I cannot give a satisfactory answer but I still believe that there is more to it than sheer expediency. One guess is that to him there was still a large grey area between what you cannot say at all and the obvious Christian doctrines relating to the Christ event. This area called for open-endedness and undecidability. In fact space was created in which to act, in which to become creative in new unexpected ways.

\section{The Hidden Story: Towards a Theology of Change as a Reflection of Ecclesial Praxis in the Early Church}

As was said in the introduction it is my contention that Marais' account of the early church is forming an ecclesiology and as a result of that an important theological reflection that could be seen as central in his thinking as a whole. It is not wholly unreasonable to assume that the subject matter of the dissertation and how that was interpreted stayed with him through his life.

Using material from the New Testament and the early church during its formation in the first three centuries he was able to formulate a doctrine of communitarian living (Christelike broederskapsleer). It is consistently portrayed as a spiritual as well as social reality. This particular living, i.e. the church, is built on Christological premises.

In applying the radical and conservative principle he is able to demonstrate how the church's lack of political awareness in the Roman Empire was compensated by a radical sharing of a koinonia-like life together in the church. Accepting slavery on one level meant a total rejection of it on another.

What we see emerging is a 'grand narrative' of the early church plagued by slavery. The result is the contours of an ecclesiology on basis of which a theology of change could develop. $^{48}$

As already indicated this largely hidden story indirectly played an important role in his ecumenical understanding, while partly held back in a radical way when dealing with the South African church.

47 It should here be mentioned that a reader of various articles of Marais hardly would come near the kind of argument that I have brought out here. It is in his dissertation where I also have pursued his references to early church fathers extensively. What you then find is that he refers to issues such as the two last ones, sometimes with references only without quotes. The pattern however is unmistakable. He consistently refuses to take a stand but rather gives Origen, Tertullian and others the space that they need. I have highlighted this procedure, Marais is the one who selected the references, see my dissertation, for example pp. $204 \mathrm{ff}$.

48 "The other suspicion is that his masterly portrayal of the early church as a moral community, not least in dealing with slavery, has been of lasting importance to Marais. This is the hidden 'grand narrative' that has impacted on his thinking and is the key to his insistence on the church as an ecumenical, largely visible reality. A lot could be said about this narrative. Suffice it to say that his argument about the early church and slavery is valid in present ecumenical discourse. The church as the moral community is not a being in splendid isolation but in intensive contact with the world”, Engdahl, p. 278. 
The close, immanent reading undertaken here is a textual exercise and does not speculate on how certain findings could have been applied or not. The powerful story on the early church and slavery also does not exonerate Marais' 'practicalities syndrome'. These are texts standing side by side in his authorship and so they will remain.

\section{Conclusion}

Three stories may be discerned in the theological texts of Marais. The Christ event I have deemed as an adequate description of what is his lead story. He is consistent in outlining this story with the broad strokes, being faithful to essentials and carefree of the rest.

The second story is the more troublesome, also I would suggest, to him. The story of the Afrikaners, South Africa with all its other peoples and the church is never brought out in clear lines but remains an underlying reality in whatever he says. No wonder, it is after all his people, his land, his church.

It is therefore of greatest importance that another third story could be found. It is largely a hidden story in Marais' theological ministry. It is remarkable that the texts that Marais has written regarding slavery in the early church are so little known.

It is my contention that this 'grand narrative' of the early church as a moral community in dealing with slavery is of fundamental importance in the theology of Ben Marais.

Even though the three stories taken together are proof of a serious lack of consistency, there is no denying that the third story makes a theology of lasting value. 


\section{BIBLIOGRAPHY ON MARAIS' MAJOR WORKS}

Marais, Barend (Ben) Jacobus, "Die Christelike broderskapsleer: sy agtergrond en toepassing in die vroeë kerk" (diss.). Stellenbosch, 1946.

- "'n Kritiese Beoordeling van die Standpunt van ons Kerk insake Rasseverhoudings met die Oog op die Gebeure Oorsee" in Op die Horison, no. 2, June 1947, pp. 65-80.

— "Die Skrif en rasse-apartheid" in Die Gereformeerde Vaandel, no. 18, 1950.

- Colour, Unsolved Problem of the West. Cape Town and London, 1952.

— "Church Transcending Nation" in The Ecumenical Review. Geneva, July 1956.

- Human Diversity and Christian Unity, Peter Ainslie Memorial Lecture. Grahamstown, 1957.

— "Die sin van die geskiedenis" in Die Gereformeerde Vaandel 25(4), 1957, pp. 21-33.

— "Die 'herlewing' van die heidendom" in Nederduits Gereformeerde Teologiese Tydskrif (NGTT), 1(1), 1959, pp. 30-39.

- Die Kerk deur die Eeue. Pretoria, 1960.

- "The Church in the Contemporary World" in Geyser, Marais et al. (eds.), Delayed Action: An ecumenical witness from the Afrikaans speaking church. Pretoria, 1960.

— "Die eksklusiewe rassekerk-'teologie' in die lig van die skrif en die kerkgeskiedenis" in Pro Veritate, 15 August 1962.

- Kerkgeskiedenis: Beknopte aantekeninge alleen ter aanvulling van klaswerk, vryelesings en selfstudie. Pretoria, 1962.

— "Die Mariologie in die Rooms-katolieke Kerk" in Nederduits Gereformeerde Teologiese Tydskrif (NGTT), 4(1), 1962, pp. 54-65.

— "Besware teen en probleme om die ekumene" in Van Wijk, AJ (ed.), Die Ekumene. 'n Besinning oor Interkerklike Verhoudinge. Stellenbosch, 1964.

- The Two Faces of Africa. Pietermaritzburg, 1964

— "Kerk en die Islam in Afrika" in Koers, 1965, pp. 173-185.

— "Was die Hervorming noodsaaklik?" in Nederduits Gereformeerde Teologiese Tydskrif (NGTT) 8(4), 1967, pp. 194-202.

— "Role of the churches in South Africa" in Reformed and Presbyterian world, 30, 1969, pp. 352-360.

— "Die eksegese van die Vaders" in Jonker, H et al. (eds.) Hermeneutica. Erebundel aangebied aan prof dr EP Groenewald..., 1970.

- "Islam: Politieke faktor in Afrika" in Bulletin van die Afrika-Instituut van Suid-Afrika 11, 1971, pp. 51-65.

— “Die prediking deur die eeue: 'n Enkele greep uit die vroeë kerk" in Marais, BJ en Boshoff, CWH (eds.) Rondom die prediking. Erebundel aangedied aan prof dr HDA du Toit..., 1972.

— "Die Kerk op weg met sy verlede" in Deo Gloria, Jaarblad van die Teologiese Fakulteit (Afd B) University of Pretoria. Pretoria, 1974.

— "Enkele stromings in die Grieks-Romeinse wêreld rondom die koms van Christus" in Theologica Evangelica 9, 1976, pp. 147-160.

— "Historical flashback: The Christian church and race (colour)" in Theologica Evangelica 10, 1977, pp. 60-72.

_ “Die NG Kerk se vereensamingspad" in Theologica Evangelica 16(3), 1983, pp. 45-50. 